\title{
Prey-capture rates in four Mediterranean cold water corals
}

\author{
Georgios Tsounis ${ }^{1, *}$, Covadonga Orejas ${ }^{1,2}$, Stéphanie Reynaud ${ }^{3}$, Josep-Maria Gilii ${ }^{1}$, \\ Denis Allemand ${ }^{3}$, Christine Ferrier-Pagès ${ }^{3}$
}

\author{
${ }^{1}$ Institut de Ciències de Mar (CSIC), Passeig Marítim de la Barceloneta 37-49, 08003 Barcelona, Spain \\ ${ }^{2}$ Centro Oceanográfico de Santander (IEO), Promontorio de San Martin s/n, 39004 Santander, Cantabria, Spain \\ ${ }^{3}$ Centre Scientifique de Monaco, Avenue Saint-Martin, 98000 Monaco (Principality)
}

\begin{abstract}
Little is known about the basic biology of deep-water coral species. In this study, we experimentally assessed the rates of ingestion of Artemia salina adults and nauplii by the 4 Mediterranean cold water coral species Dendrophyllia cornigera, Desmophyllum cristagalli, Madrepora oculata, and Lophelia pertusa. All species ingested A. salina in adult and nauplii forms. L. pertusa showed the highest grazing rate for both prey types, whereas M. oculata showed the lowest capture rates among the 4 species, and was practically unable to ingest adult prey. Capture rates of the 4 coral species ranged between 5 and 8 adult $A$. salina, and 50 and 280 nauplii polyp $\mathrm{p}^{-1} \mathrm{~h}^{-1}$. Surprisingly, both capture rates and carbon uptake (adult Artemia ingestion: 994 to $3542 \mu \mathrm{g} \mathrm{C}$ polyp ${ }^{-1} \mathrm{~h}^{-1}$; nauplii ingestion: 78.1 to $462 \mu \mathrm{g} \mathrm{C}$ polyp ${ }^{-1} \mathrm{~h}^{-1}$ ) were within the range of values found in some tropical corals (which often ingest 0.004 to 3600 prey items poly ${ }^{-1} \mathrm{~h}^{-1}$ ). The results show that the capture rates and energy input of the studied cold water coral species appear to be on a level that is comparable to that of other corals, even tropical zooxanthellate species.
\end{abstract}

KEY WORDS: Cold water corals $\cdot$ Grazing rates $\cdot$ Colony size $\cdot$ Trophic ecology $\cdot$ Benthic-pelagic coupling

Resale or republication not permitted without written consent of the publisher

\section{INTRODUCTION}

Cold water coral (CWC) communities are receiving increased attention as they support rich biodiversity and high fish abundances (Auster 2007, Spencer et al. 2007). However, little is known about the basic biology of deep-water coral species, in terms of growth rates, life cycle, and feeding.

Corals in general can meet their energy demands in a number of ways (Lasker 1981, Sebens \& Koehl 1984, Freiwald 1998, Gili \& Coma 1998, Orejas et al. 2001), and studies mostly performed on tropical corals have shown that they are able to prey on zooplankton (Muscatine \& Porter 1977, Sebens 1987), phytoplankton (Fabricius 1998), pico-nanoplankton (Al-Moghrabi et al. 1993, Houlbrèque et al. 2004b), and dissolved organic matter (Grover et al. 2008). Energy can also be gained through zooxanthellae photosynthesis in sym- biotic species (Muscatine 1990, Fabricius \& Klumpp 1995, Houlbrèque \& Ferrier-Pagès 2009), or possibly through ingestion of chemosynthetic bacteria in coldseep species (Hovland et al. 1998, Hovland \& Risk 2003).

No direct estimates of grazing rates in CWC are available at this time, but stochiometric analysis of the CWC Lophelia pertusa and Madrepora oculata from the Atlantic suggested that they might be omnivores rather than exclusive herbivores (Roberts et al. 2003, 2006), and might even feed primarily on mesozooplankton (Duineveld et al. 2004, Kiriakoulakis et al. 2005). Observations during research dives by manned submersible confirmed the abundant presence of zooplankton over CWC communities (Fig. 1). Zooplankton is an energy-rich food source that can, even in tropical zooxanthellate corals, significantly increase growth rates (Houlbrèque et al. 2003, 2004b). In fact, CWC 


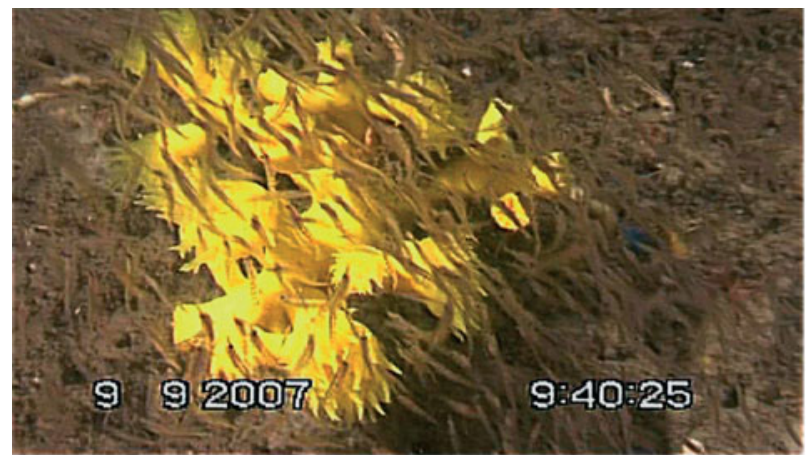

Creus Canyon (Gulf of Lyons, NW Mediterranean) and off the Island of Malta: Dendrophyllia cornigera, Lophelia pertusa (collected in September 2007 at $42^{\circ} 23.187^{\prime} \mathrm{N}, 03^{\circ} 19.273^{\prime} \mathrm{E}$; $300 \mathrm{~m}$ depth, by submersible), Desmophyllum cristagalli (April 2007 in Malta $35^{\circ} 30.506^{\prime} \mathrm{N}, 14^{\circ} 06.230^{\prime} \mathrm{E}$; $632 \mathrm{~m}$ depth, and at $35^{\circ} 30.76^{\prime} \mathrm{N}, 14^{\circ} 06.42^{\prime} \mathrm{E}$; $585 \mathrm{~m}$ depth using an epibenthic sledge), Madrepora oculata (July 2006, $42^{\circ} 23.760^{\prime} \mathrm{N}, 3^{\circ} 18.902^{\prime} \mathrm{E} ; 218 \mathrm{~m}$ depth by remotely operated vehicle [ROV]). The collection tools used were either an epibenthic sledge on board the RV 'Urania' during the cruise 'MARCOS', or a ROV Phantom HD2 + 2, and the manned submersible JAGO (IFM-GEOMAR) on board the RV 'García del Cid' during the cruises 'Deep Coral I_Coral4' and 'HERMES IV_Coral8.'

Dendrophyllia cornigera forms colonies of $15 \mathrm{~cm}$ in height with large polyps of 2 to $4 \mathrm{~cm}$ in diameter, and can be found between 200 and $800 \mathrm{~m}$ depth, but locally as shallow as $30 \mathrm{~m}$ depth (Castric-Fey 1996). Cairns \& Zibrowius (1997) considered Desmophyllum cristagalli to be a junior synonym of $D$. dianthus. This species forms solitary polyps of 5 to $10 \mathrm{~cm}$ in height and 1.5 to $3 \mathrm{~cm}$ in diameter, and lives between 100 and $4000 \mathrm{~m}$ depth (Risk et al. 2002). The polyps measure ca. 1.5 to $2 \mathrm{~cm}$ in height. Madrepora oculata forms fragile fanshaped or cauliflower-like colonies of 30 to $50 \mathrm{~cm}$ in height and has small polyps of 3 to $5 \mathrm{~mm}$ in diameter. It can be found as shallow as $55 \mathrm{~m}$ depth off Brazil and as deep as $1950 \mathrm{~m}$ off Iceland (Zibrowius 1980). Lophelia pertusa polyps are about 5 to $15 \mathrm{~mm}$ in height and ca. $1 \mathrm{~cm}$ in diameter, and their colonies grow to a size of more than $130 \mathrm{~cm}$ (Gass \& Roberts 2006) and form reefs as high as $33 \mathrm{~m}$ (Mortensen et al. 2001). This species dwells mostly between 100 and $400 \mathrm{~m}$ depth, but has been found at depths of 40 to $3000 \mathrm{~m}$ (Zibrowius 1980, Cairns 1994, Freiwald 1998, Fosså et al. 2002).

In the laboratory, corals were maintained for several months to $>1 \mathrm{yr}$ in tanks cooled to $12^{\circ} \mathrm{C}$, which nearly matches the temperature recorded at the Cap de Creus Canyon (Canals et al. 2006, Palanques et al. 2006). Corals were fed 5 times per week (once daily) with Artemia salina nauplii. No damage of the corals from sampling was observed, and the animals continued to survive and grow in the aquaria at the time of writing this manuscript. Four replicated feeding experiments per species (using different colonies) and prey type were conducted in incubation chambers, using a setup that consisted of 3 PVC rectangular chambers $\left(850 \mathrm{ml}_{\text {; }}\right.$ dimensions: $200 \times 50 \times 80 \mathrm{~mm}$ ) fitted with stirrers with a defined rotational speed. The 3 chambers were in a common water bath to maintain a constant temperature. The system was designed to create a laminar current that circulates around a platform situated in the middle of the chamber (for a detailed description, see were collected at 150 to $250 \mathrm{~m}$ depth at the Cap de 
Houlbrèque et al. 2004a). Corals were starved the night prior to the day of the experiment and were placed in the path of the current forcing the prey to repeatedly pass the location until all prey was captured. All experiments were conducted with the minimum flow rate, inducing a current speed of about $1 \mathrm{~cm}$ $\mathrm{s}^{-1}$, and was just strong enough to prevent the prey from navigating within the chamber at will, and instead being swept with the current with little control over direction.

The first prey type chosen were adult Artemia salina (ca. 8 to $10 \mathrm{~mm}$ in length). Both smaller and larger zooplankton organisms were observed during the ROV and JAGO dives (especially Euphausiacea, see Fig. 1), indicating that $A$. salina matches the characteristics of some of the potential prey in the natural habitat. Using live crustacean prey for feeding experiments allows us to consider the efficiency of capturing prey that, once captured, is actively trying to free itself from the tentacles.

One small colony (in the case of Madrepora oculata and Lophelia pertusa) or solitary polyp (for Dendrophyllia cornigera and Desmophyllum cristagalli) was placed into each chamber filled with seawater at $12^{\circ} \mathrm{C}$. After an acclimation time of $30 \mathrm{~min}$ or after polyps opened, 20 adult Artemia salina were added to the chamber (23.53 prey items $\mathrm{l}^{-1}$ ), and their capture by the corals was observed and recorded during an incubation time of $30 \mathrm{~min}$ to $2 \mathrm{~h}$ (experiments were stopped when the prey quantity in the incubation chamber remained constant, i.e. when the corals stopped feeding). The size of adult $A$. salina, the transparent acrylic material of the chambers, and the efficient capture rate of the corals made direct observation by eye possible. Number of prey ingested was normalized to the number of active polyps. In addition, 4 control experiments per prey type (prey only, without corals) showed that the activity and number of prey remained constant during the incubation.

Live Artemia salina nauplii larvae (ca. $0.25 \mathrm{~mm}$ in length) were used as alternative prey in a second set of experiments in order to record the capture of smaller zooplankton prey. All experiments started with a prey concentration of 10 to 20 nauplii $\mathrm{ml}^{-1}$. The nauplii were quantified using a dolphus chamber (Riera \& Hubas 2003).

Capture rates for both prey sizes were expressed as number of prey polyp $\mathrm{p}^{-1} \mathrm{~h}^{-1}$, and were compared among species using a 1-way analysis of variance (ANOVA; and subsequent Tukey test if appropriate), after confirming that variances were equal (Levene test) and data were normally distributed. Since Madrepora oculata rarely ingested this prey type, we failed to obtain a large enough data sample to include in the ANOVA analysis for adult prey. Carbon content was determined using conversion factors by Szyper (1989).

\section{RESULTS AND DISCUSSION}

All 4 coral species captured Artemia salina nauplii, and 3 of them captured adults as well. Overall, the capture rates per polyp for the 4 species ranged from 5 to 8 adults polyp $\mathrm{p}^{-1} \mathrm{~h}^{-1}$ and from 50 to 280 nauplii polyp ${ }^{-1} \mathrm{~h}^{-1}$ (Table 1). Capture rates for adults were not significantly different among the 4 coral species (ANOVA, $F=1.72$, $\mathrm{p}=0.22$ ), while for nauplii, Lophelia pertusa captured significantly more than the other 3 species (ANOVA, $F=7.7, \mathrm{p}=0.0033$. The polyps were able to capture prey even when expanded only partially. After the experiments, polyps remained saturated and unable to ingest more prey for the next 12 to $24 \mathrm{~h}$. However, the tentacles continued to retain prey, which was either ingested after a period of partial digestion or lost in the current.

Although some studies have demonstrated efficient capture of zooplankton by CWC (e.g. Freiwald 1998), the role of zooplankton in their diet has been questioned in the past. The point raised was that the food spectrum in CWC habitats is possibly lacking zooplankton (Kiriakoulakis et al. 2005), or that the corals were lacking sufficient nematocysts to be able to capture it, as already observed in some tropical shallow water octocoral species (Briareum asbestinum, Pseudoplexaura porosa, Pseudopterogorgia americana; Lasker 1981). However, stochiometric studies on CWC have led to the conclusion that zooplankton must be a significant part of their diet (Duineveld et al. 2004, Kiriakoulakis et al. 2005, Dodds et al. in press). We can therefore assume that the CWC studied obtain a part of their diet from capturing zooplankton, as is typical for scleractinian corals in general (Porter 1974, Muscatine \& Porter 1977, Sebens 1977, 1987). Mediterranean examples of anthozoans capturing zooplankton include the shallow water octocoral (i.e. gorgonians) or alcyonacean species Alcyonium siderium, Paramuricea clavata, and Leptogorgia sarmentosa (Coma et al. 1994, Ribes et al. 1998, Rossi et al. 2004). Capture of phytoplankton and bacterioplankton or uptake of dissolved organic matter (DOM) have also been observed among corals and octocorals (Fabricius 1998, Orejas et al. 2001, 2003, Ribes et al. 2003, Picciano \& Ferrier-Pagès 2007, Grover et al. 2008), and some Mediterranean species are more or less omnivorous, taking advantage of a wide spectrum of food sources (Ribes et al. 2003, Tsounis et al. 2006). Further research may therefore identify a larger variety of prey types among CWC as well. However, among possible prey types, zooplankton offers the highest energy value, as tropical scleractinian corals have been found to increase their growth by 50 to $75 \%$ when a zooplankton diet complements phototrophy (Houlbrèque et al. 2003). Furthermore, when fed with zooplankton, the CWC Lophelia pertusa and Madrepora oculata 


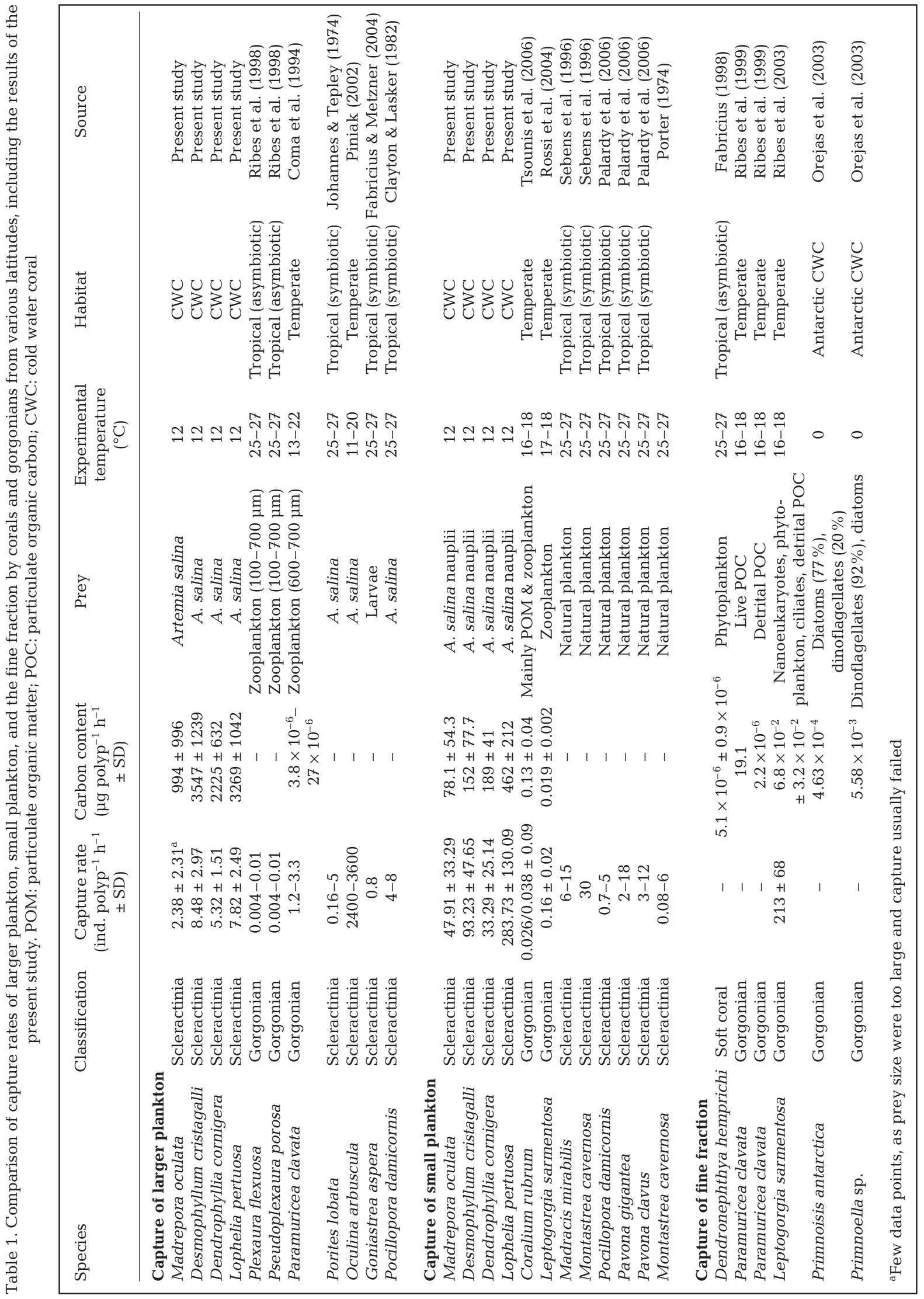


showed growth rates in the same range as some tropical corals (Orejas et al. 2008). Thus when zooplankton is available, it likely represents an important part of the diet of corals.

The chosen prey type in this study is at best only representative for a small part of their food spectrum, but these experiments do demonstrate the feeding efficiency of the 4 studied coral species for this kind of prey. In fact, the results reveal some differences in the feeding capacities among the corals. In this study, Madrepora oculata usually failed to capture adult Artemia salina (despite some data points that are included in the table, but were not sufficient to meet ANOVA requirements). Although we did not focus on determining the cause for these differences, it is known that species differing in colony size, colony structure, polyp size, tentacle size, and nematocyst density on the tentacles capture a different size spectrum of prey (Lasker 1981, Sebens \& Koehl 1984, Palardy et al. 2005). The polyps of Dendrophyllia cornigera and Desmophyllum cristagalli are much larger (20 to $40 \mathrm{~mm}$ in diameter) than those of Lophelia pertusa and M. oculata (3 to $10 \mathrm{~mm}$ in diameter), and thus a much higher capture rate would be expected in the former species. However, our results showed that the D. cornigera and D. cristagalli colonies did not capture significantly more prey than L. pertusa, which proved to be a relatively voracious grazer despite its smaller polyp size (Fig. 2). The potential prey size spectrum that this species can efficiently capture is remarkably ample, as aquarium and in situ observations have provided evidence that $L$. pertusa is able to selectively capture live zooplankton up to $2 \mathrm{~cm}$ in size (Mortensen 2001, Freiwald 2002). The high capture rate of $A$. salina nauplii may indicate that this prey lies within the optimal prey size range for the 4 studied CWC species, but further research is needed to confirm this observation. Although the 4 species captured nauplii at a higher rate than adults, capture of nauplii results in lower energetic input, since the energetic value of adult Artemia sp. (see Table 1) is much higher than that of nauplii. However, juvenile Artemia sp. have a much lower energetic value (Szyper 1989) so that their capture may result in a lower energy input as in the case of nauplii larvae.

In comparison to other corals, even tropical zooxanthellate species such as Stylophora pistillata (FerrierPagès et al. 2003), it appears that the capture rates and energy input of the studied CWC species are on a comparable level (Table 1). Some studies on other corals used a similar experimental set up, so that the comparison of results should be valid (Ribes et al. 1998, Orejas et al. 2003, Houlbréque et al. 2004a). However, some tropical corals might have low capture rates due to complementing their energy demand with zooxanthel-
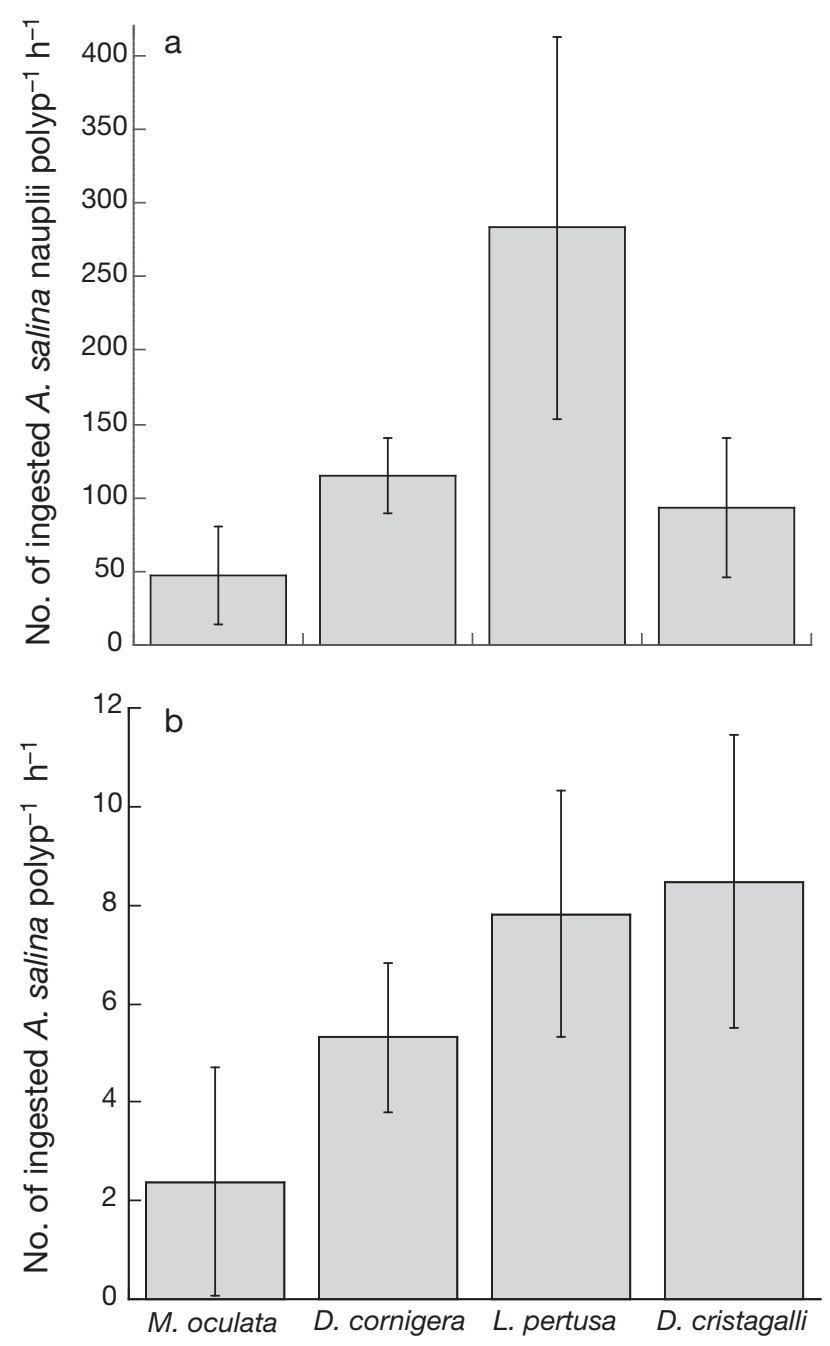

Fig. 2. Madrepora oculata, Dendrophyllia cornigera, Lophelia pertusa, and Desmophyllum cristagalli. Capture rates (expressed as average \pm SD) of Artemia salina (a) adults and (b) nauplii larvae

lae. In contrast to tropical corals, CWC dwell in a habitat with low temperature, which implies lower energy expenditure. Thus CWC may be able to exploit a large amount of energy from potentially short zooplankton pulses, and possibly survive even if such pulses are sparse.

In general, feeding rates measured with incubation chamber experiments are difficult to extrapolate to the natural environment, since the natural habitat has extremely varying conditions. In situ capture rates might vary according to the current speed and prey availability and may be in the form of pulses (Omori \& Hamner 1982, LaBarbera 1984, Eckman \& Duggins 1993, Kim \& Lasker 1997). Caution must therefore be used when extrapolating capture rates obtained in the laboratory to in situ conditions. 
Future studies may determine the grazing impact of these coral species on the ecosystem by utilizing a biometrical characterization of the colony morphology, as e.g. Madrepora oculata colonies have far more polyps than Dendrophyllia cornigera and Desmophyllum cristagalli and will therefore capture more prey despite a lower capture rate per polyp. Future research should also include studies on population structure, digestion times, and activity rhythms of CWC, as well as studies on the temporal and spatial distribution and dynamics of zooplankton in the near bottom layer. These studies will ultimately improve our understanding of biogeochemical fluxes in deep ocean habitats, and the ecology of CWC.

Acknowledgements. We thank C. Rottier for invaluable help in the laboratory, F. Houlbrèque for help in preparing the experiments, A. Gori and B. Vendrell for coral maintenance, A. Olariaga and A. Gori for setting up the aquarium facilities at ICM (CSIC), the crews of the RVs 'García del Cid' and 'Urania' as well as to the JAGO team (J. Schauer and K. Hissmann) from IFM-GEOMAR, M. Taviani for supporting the maintenance of living corals on board the 'Urania,' and P. Montagna for help in maintaining the live corals on board. G.T. was supported by a postdoctoral fellowship by the Spanish Ministry for Science and Innovation (E-08-2007-1673618) and C.O. was supported by a I3P postdoctoral contract from CSIC (I3P-PC2006L), co-financed by the European Social Fund. This study was developed within the frame of the European project HERMES (Goce-CT-2005-511234-I), the research projects from the Spanish Ministry of Science and Innovation DEEP CORAL (CTM2005-07756-C02-02/MAR), as well as the Acciones Complementarias (CTM2006-27063E/MAR, CTM2007-28758-E/MAR). Thanks to 3 anonymous reviewers who helped to improve the manuscript.

\section{LITERATURE CITED}

Al-Moghrabi S, Allemand D, Jaubert J (1993) Valine uptake by the scleractinian coral Galaxea fascicularis: characterisation and effect of light and nutritional status. J Comp Physiol B 163:355-362

Auster PJ (2007) Linking deepwater corals and fish populations. Bull Mar Sci 81:93-99

Cairns SD (1994) Scleractinia of the temperate North Pacific. Smithson Contrib Zool 557:1-150

Cairns SD, Zibrowius H (1997) Cnidaria Anthozoa: azooxanthellate Scleractinia from the Philippine and Indonesian regions. Mem Mus Nat Hist Nat Paris 172:27-243

Canals M, Puig P, Durrieu de Madron X, Heussner S, Palanques A, Fabres J (2006) Flushing submarine canyons. Nature 444:354-357

Castric-Fey A (1996) The scleractinian Dendrophyllia cornigera in shallow water, at Ushant (Brittany, NE Atlantic), related to the absence of a thermic barrier. Oceanol Acta 19:665-671

- Clayton WS, Lasker HR (1982) Effect of light and darkness treatments on feeding by the reef coral Pocillopora damicornis (Linnaeus). J Exp Mar Biol Ecol 63:269-279

Coma R, Gili JM, Zabala M (1994) Feeding and prey capture cycles in the aposymbiotic gorgonian Paramuricea clavata. Mar Ecol Prog Ser 115:257-270
Dodds LA, Black KD, Orr H, Roberts JM (2009) Lipid biomarkers reveal geographical differences in food supply to the cold-water coral Lophelia pertusa (Scleractinia). Mar Ecol Prog Ser 397:113-124

> Duineveld GCA, Lavaleye MSS, Berghuis EM (2004) Particle flux and food supply to a seamount cold-water coral community (Galicia Bank, NW Spain). Mar Ecol Prog Ser 277: $13-23$

Eckman JE, Duggins DO (1993) Effects of flow speed on growth of benthic suspension feeders. Biol Bull (Woods Hole) 185:28-41

Fabricius K (1998) In situ depletion of phytoplankton by an azooxanthelate soft coral. Limnol Oceanogr 43:354-356

Fabricius KE, Klumpp DW (1995) Widespread mixotrophy in reef-inhabiting soft corals: the influence of depth, and colony expansion and contraction on photosynthesis. Mar Ecol Prog Ser 125:195-204

> Fabricius KE, Metzner J (2004) Scleractinian walls of mouths: predation on coral larvae by corals. Coral Reefs 23: 245-248

Ferrier-Pagès C, Witting J, Tambutté E, Sebens KP (2003) Effect of natural zooplankton feeding on the tissue and skeletal growth of the scleractinian coral Stylophora pistillata. Coral Reefs 22:229-240

> Fosså JH, Mortensen PB, Furevik DM (2002) The deep-water coral Lophelia pertusa in Norwegian waters: distribution and fishery impacts. Hydrobiologia 471:1-12

Freiwald A (1998) Geobiology of Lophelia pertusa (Scleractinia) reefs in the north Atlantic. Habilitation thesis, University of Bremen

Freiwald A (2002) Reef forming cold water corals. In: Wefer G, Billet D, Hebeln D, Jørgensen BB, Schlüter M, van Weering $\mathrm{T}$ (eds) Ocean margin systems. Springer, Berlin, p 365-385

Gass SE, Roberts JM (2006) The occurrence of the cold-water coral Lophelia pertusa (Scleractinia) on oil and gas platforms in the North Sea: colony growth, recruitment and environmental controls on distribution. Mar Pollut Bull 52:549-559

Gili JM, Coma R (1998) Benthic suspension feeders: their paramount role in littoral marine food webs. Trends Ecol Evol 13:316-321

Grover R, Maguer JF, Allemand D, Ferrier-Pagès C (2008) Uptake of dissolved free amino acids (DFAA) by the scleractinian coral Stylophora pistillata. J Exp Biol 211:860-865

Houlbrèque F, Ferrier-Pagès C (2009) Heterotrophy in tropical scleractinian corals. Biol Rev Camb Philos Soc 84:1-17

- Houlbrèque F, Tambutté E, Ferrier-Pagès C (2003) Effect of zooplankton availability on the rates of photosynthesis, and tissue and skeletal growth in the scleractinian coral Stylophora pistillata. J Exp Mar Biol Ecol 296:145-166

Houlbrèque $F$, Tambutté $E$, Allemand $D$, Ferrier-Pagès $C$ (2004a) Interactions between zooplankton feeding, photosynthesis and skeletal growth in the scleractinian coral Stylophora pistillata. J Exp Biol 207:1461-1469

Houlbrèque $F$, Tambutté $E$, Richard $C$, Ferrier-Pagès C (2004b) Importance of a micro-diet for scleractinian corals. Mar Ecol Prog Ser 282:151-160

> Hovland M, Risk M (2003) Do Norwegian deep-water coral reefs rely on seeping fluids? Mar Geol 198:83-96

> Hovland M, Mortensen PB, Brattegard T, Strass P, Rokoengen K (1998) Ahermatypic coral banks off mid-Norway: evidence for a link with seepage of light hydrocarbons. Palaios 13:189-200

Johannes RE, Tepley L (1974) Examination of feeding on the reef coral Porites lobata in situ using time lapse photography. Proc 2nd Int Coral Reef Symp Brisbane 1:127-131 
Kim K, Lasker HR (1997) Flow-mediated resource competition in the suspension feeding gorgonian Plexaura homomalla (Esper). J Exp Mar Biol Ecol 215:49-64

Kiriakoulakis K, Fisher L, Freiwald A, Grehan A, Roberts M, Wolff GA (2005) Lipids and nitrogen isotopes of two deepwater corals from the North-East Atlantic: initial results and implications for their nutrition. In: Freiwald A, Roberts JM (eds) Cold-water corals and ecosystems. SpringerVerlag, Berlin, p 715-729

LaBarbera M (1984) Feeding currents and particle capture mechanisms in suspension feeding animals. Am Zool 24: 71-84

Lasker HR (1981) A comparison of the particulate feeding abilities of three species of gorgonian soft coral. Mar Ecol Prog Ser 5:61-67

Mortensen PB (2001) Aquarium observations on the deep water coral Lophelia pertusa (L. 1758) (Scleractinia) and selected associated invertebrates. Ophelia 54:83-104

Mortensen PB, Hovland T, Fosså JH, Furevik DM (2001) Distribution, abundance and size of Lophelia pertusa coral reefs in mid-Norway in relation to seabed characteristics. J Mar Biol Assoc UK 81:581-597

Muscatine L (1990) The role of symbiotic algae in carbon and energy flux. In: Dubinsky Z (ed). Ecosystems of the world. Elsevier, New York, p 75-84

Muscatine L, Porter JW (1977) Reef corals: mutualistic symbioses adapted to nutrient-poor environments. Bioscience 27:454-460

> Omori M, Hamner WM (1982) Patchy distribution of zooplankton: behaviour, population assessment and sampling problems. Mar Biol 72:193-200

> Orejas C, Gili JM, López-Gonzalez PJ, Arntz WE (2001) Feeding strategies and diet composition of four Antarctic cnidarian species. Polar Biol 24:620-627

Orejas C, Gili JM, Arntz WE (2003) The role of the small planktonic communities in the diet of two Antarctic octocorals (Primnoisis antarctica and Primnoella sp.). Mar Ecol Prog Ser 250:105-116

> Orejas C, Gori A, Gili JM (2008) Growth rates of live Lophelia pertusa and Madrepora oculata from the Mediterranean Sea maintained in aquaria. Coral Reefs 27:255

Palanques A, Durrieu de Madron X, Puig P, Fabres J and others (2006) Suspended sediment fluxes and transport processes in the Gulf of Lions submarine canyons. The role of storms and dense water cascading. Mar Geol 234:43-61

> Palardy JE, Grottoli AG, Matthews KA (2005) Effects of upwelling, depth, morphology and polyp size on feeding in three species of Panamanian corals. Mar Ecol Prog Ser 300:79-89

Palardy JE, Grottoli AG, Matthews KA (2006) Effect of naturally changing zooplankton concentrations on feeding rates of two coral species in the eastern Pacific. J Exp Mar Biol Ecol 331:99-107

Picciano M, Ferrier-Pagès C (2007) Ingestion of pico- and nanoplankton by the Mediterranean red coral Corallium rubrum. Mar Biol 150:773-782

Piniak GA (2002) Effects of symbiotic status, flow speed, and prey type on prey capture by the facultatively symbiotic temperate coral Oculina arbuscula. Mar Biol 141: 449-455

Porter JW (1974) Zooplankton feeding by the Caribbean reefbuilding coral Montastrea cavernosa. Proc 2nd Int Coral Reef Symp p 111-125

Editorial responsibility: Hans Heinrich Janssen, Oldendorf/Luhe, Germany
Ribes M, Coma R, Gili JM (1998) Heterotrophic feeding by gorgonian corals with symbiotic zooxanthella. Limnol Oceanogr 43:1170-1179

Ribes M, Coma R, Gili JM (1999) Heterogenous feeding in benthic suspension feeders: the natural diet and grazing rate of the temperate gorgonian Paramuricea clavata (Cnidaria: Octocorallia) over a year cycle. Mar Ecol Prog Ser 183:125-137

- Ribes M, Coma R, Rossi S (2003) Natural feeding of the temperate asymbiotic octocoral-gorgonian Leptogorgia sarmentosa (Cnidaria: Octocorallia). Mar Ecol Prog Ser 254: $141-150$

Riera P, Hubas C (2003) Trophic ecology of nematodes from various trophic habitats of the Roscoff Aber bay: importance of stranded macroalgae evidence through $\delta 13 \mathrm{C}$ and 反15N. Mar Ecol Prog Ser 260:151-159

Risk MJ, Heikoop JM, Snow MG, Beukens R (2002) Lifespans and growth patterns of two deep-sea corals: Primnoa resedaeformis and Desmophyllum cristagalli. Hydrobiologia 471:125-131

Roberts JM, Wilson JB, Mortensen PB, Gage JD (2003) The cold water coral Lophelia pertusa (Scleractinia) and enigmatic seabed mounds along the north-east Atlantic margin: Are they related? Mar Pollut Bul 46:7-20

> Roberts JM, Wheeler AJ, Freiwald A (2006) Reefs of the deep: the biology and geology of cold-water coral ecosystems. Science 312:543-547

Rossi S, Ribes M, Coma R, Gili JM (2004) Temporal variability in zooplankton prey capture rate of the soft bottom passive suspension feeder Leptogorgia sarmentosa (Cnidaria: Octocorallia), a case study. Mar Biol 144:89-99

Sebens KP (1977) Autotrophic and heterotrophic nutrition of coral reef zoanthids. In: Taylor DL (ed). Proc 3rd Int Coral Reef Symp Univ Miami: 398-404

Sebens KP (1987) The ecology of indeterminate growth in animals. Annu Rev Ecol Syst 18:371-407

Sebens KP, Koehl MAR (1984) Predation on zooplankton by the benthic anthozoans Alcyonium siderium (Alcyonacea) and Metridium senile (Actiniaria) in the New England subtidal. Mar Biol 81:255-271

> Sebens KP, Vandersall KS, Savina LA, Graham KR (1996) Zooplankton capture by two scleractinian corals Madracis mirabilis and Montastrea cavernosa in a field enclosure. Mar Biol 127:303-317

Spencer JH, Rogers A, Davies J, Foggo A (2007) Deep-sea coral distribution on seamounts, oceanic islands, and continental slopes in the Northeast Atlantic. In: George RY, Cairns SD (eds) Conservation and adaptive management of seamount and deep-sea coral ecosystems. Rosenstiel School of Marine and Atmospheric Science, University of Miami, Miami, FL, p 135-146

Szyper JP (1989) Nutritional depletion of the aquaculture feed organisms Euterpina acutifrons, Artemia sp. and Brachionus plicatilis during starvation. J World Aquacult Soc 20:162-169

> Tsounis G, Rossi S, Laudien J, Bramanti L, Fernández N, Gili JM, Arntz WE (2006) Diet and seasonal prey capture rates in the Mediterranean red coral (Corallium rubrum L.). Mar Biol 149:313-325

Zibrowius H (1980) Les scléractinies de la Méditerranée et de l'Atlantique nord-oriental. Mem Inst Oceanogr (Monaco) 11:1-284

Submitted: June 12, 2009; Accepted: September 8, 2009 Proofs received from author(s): December 1, 2009 